\title{
A DIFÍCIL RELAÇÃO ENTRE O DIREITO FUNDAMENTAL À INFORMAÇÃO E O ACESSO AOS DOCUMENTOS PRODUZIDOS PELO REGIME MILITAR BRASILEIRO
}

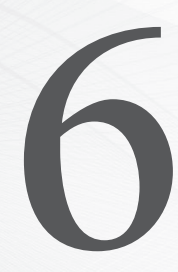

Rogério Gesta Leal

Doutor em Direito. Coordenador Científico do Núcleo de Pesquisa Judiciária da Escola Nacional de Formação e Aperfeiçoamento da Magistratura (Enfam). Coordenador do Comitê de Gestão da Rede dos Observatórios do Direito à Verdade, Memória e Justiça nas Universidades Brasileiras, junto à Secretaria de Direitos Humanos da Presidência da República. Professor Visitante da Università Tullio Ascarelli - Roma Trè, Universidad de La Coruña (Espanha) e Universidad de Buenos Aires. Professor da Escola Nacional de Formação e Aperfeiçoamento da Magistratura - Enfam. Professor da Universidade do Oeste de Santa Catarina (Unoesc). Membro do Conselho Científico do Observatório da Justiça Brasileira e da Rede de Direitos Fundamentais (Redir), do Conselho Nacional de Justiça. Desembargador do Tribunal de Justiça do Estado do Rio Grande do Sul.

Autor convidado

ÁreA Do DiReITo: Constitucional

Resumo: Pretendo neste ensaio abordar a dificil relação entre o Direito Fundamental à Informação e o problema do acesso aos documentos produzidos pelo regime militar brasileiro, fazendo uma análise pontual sobre os marcos normativos que sustentam este debate ainda hoje.

Palavras-chave: Democracia - Direito fundamental à informação - Segredo de Estado.

\begin{abstract}
I want to approach in this essay the difficult relationship between the fundamental right to information and the problem of access to documents produced by the Brazilian military regime, making a timely analysis of the legal frameworks underpinning this debate today.
\end{abstract}

KEYWORDS: Democracy - Information fundamental right - State secret. 


\section{NOTAS INTRODUTÓRIAS}

Pretendo tratar, neste ensaio, de algumas questões preambulares envolvendo o tema da relação entre o Direito Fundamental à Informação e o problema do acesso aos documentos produzidos pelo regime militar brasileiro.

Para a discussão desta matéria, pretendo inicialmente estabelecer alguns marcos teórico-filosóficos e políticos atinentes à questão da importância da (a) informação e do conhecimento à (b) democracia contemporânea, e o farei a partir de (c) interlocuções com alguns textos de Jürgen Habermas, para, a partir de então, avaliar de que maneira a informação e o conhecimento sobre os documentos produzidos pelo regime militar brasileiro se constituem em Direito Fundamental Individual (dos atingidos direta ou indiretamente por ele) e Social (relacionados à Sociedade Civil nacional).

No cotejamento do debate, pretendo ainda avaliar o evolver normativo internacional e nacional de acesso público às informações de Estado e de que forma os Tribunais brasileiros têm abordado estas questões, analisando criticamente as possibilidades, principalmente de acesso aos documentos sob comento, já disponibilizados pelo sistema arquivístico público do país, e os chamados documentos secretos que ainda não estão disponíveis.

\section{Conhecimento e interesse: Uma ABORdagem habermasiana}

Em linhas gerais, pode-se dizer que a sociedade de informação em que se vive hoje tem progressivamente amainado as distâncias e mesmo os obstáculos à comunicação entre as pessoas, a ponto de que, nos recantos mais isolados do planeta, é possível obter informações do que está acontecendo, em tempo real, nas grandes metrópoles do Ocidente e mesmo do Oriente, o que nem sempre foi a realidade cotidiana.

Em termos políticos e administrativos houve tempo - não muito longínquo e quiçá ainda vigente em alguns territórios - que a regra era o segredo enquanto ausência de informação e comunicação, viabilizando autoritarismos e regimes ditatoriais das mais diversas formas e modalidades - físicos, simbólicos, burocráticos etc.

Em termos históricos esta ideia de segredo já estava presente na cultura Ocidental desde os romanos, envolvendo os desígnios políticos da comuna sob estrito conhecimento, primeiro, do representante de Deus na terra, o Imperador, depois os ilustrados que entendiam suas mensagens e as mundanizavam mais, os Senadores. 
Na própria Bíblia se pode vislumbrar a presença do segredo com três significados específicos, a saber: "in primo luogo, per indicare le cose non conoscibili di per sé (segreti del futuro, della natura, ecc.); poi, per indicare le cose confidenziali: la voce sod, usada nel texto in língua ebraica, significava originariamente divano, da cui consiglio o riunione de coloro che siedono sul divano, quindi anche ciò che si tratta in consiglio ristretto e non deve essere divulgato, ovvero è segreto; infine, tale termine é usato per indicare i luoghi nascosti". ${ }^{1}$

A era das luzes modernas contribuiu em muito para a transposição destes períodos obscurantistas, e no âmbito jurídico Brugaletta assevera que: "Tutte le barriere burocratiche elevate dal diritto napoleonico, volte a costruire il segreto più impenetrabile sull'attività amministrativa degli stati post-ottocenteschi, stanno cadendo, prima ancora che per effetto dell'azione delle riforme democratiche, per cambiamenti di realtà di fatto che s'impongono al legislatore. E forse le due cose, democrazia e informazione, possono essere due aspetti, l'uno politico e l'altro tecnologico, della stessa realtà che sta cambiando velocemente sotto l'impulso della rivoluzione telematica". ${ }^{2}$

Alguns especialistas são mais incisivos nesta matéria e sustentam que os níveis de democracia da sociedade contemporânea dependem dos respectivos índices de difusão das informações em seu cotidiano, outorgando ao cidadão a possibilidade de, assim, participar ativamente no espaço público e privado, resguardado, por certo, os direitos fundamentais de cada qual. Em especial no que diz com a coisa pública, tais informações se referem às leis, sentenças, disposições administrativas, e quaisquer outros documentos que se refiram a interesses passíveis de publicação. ${ }^{3}$

1. Orestano, Ricardo. Sulla problemática del segreto. Roma: Mulino, 2009. p. 59.

2. Brugaletta, Francesco. Poteri pubblici e dovere di disseminazione: l'altra faccia del diritto all'informazione. Rivista Diritto \& diritti. Disponível em: [www.diritto.it/articoli/informática/relazionedue.html]. Acesso em: 06.04.2011, p. 4. Diz o autor ainda que: "Già nella sensibilità letteraria del 700 la pubblicità degli atti del potere, categoria dell'illuminismo e componente essenziale del mito solare della rivoluzione, costituiva uno dei criteri fondamentali per contraddistinguere lo stato costituzionale dallo stato assoluto... l'azione pubblica, da sempre trincerata dietro un manto di impermeabilità, diventa penetrabile dal privato. Il passaggio dalla dimensione segreta alla sfera della pubblicità è testimoniata dalla rifondazione del segreto di ufficio che, da regola, diventa eccezione, operante solo nelle ipotesi legislativamente scolpite".

3. Na mesma direção vai Della Torre, Zucchetti. Privacy e accesso ai documenti amministrativi. Roma: Giuffrè, 2009. p. 76: "Dare al cittadino informazioni, significa dargliele 'gratis'[1], fornendo un servizio pubblico allo stesso modo del servizio sanitario, dell'istruzione, ecc. E siccome oggi dare informazioni significa darle a mezzo di stru- 
Em trabalho já clássico de Jürgen Habermas - e também revisado pelo autor em momentos posteriores a sua escrita - há nítida reivindicação da unidade indissociável de conhecimento e interesse, demonstrando que a neutralidade das ciências é uma exigência que não resiste ao exame crítico das condições do conhecimento como tal, pelo simples fato de que este invariavelmente está arraigado em certos interesses. ${ }^{4}$

$\mathrm{Na}$ base de tal reflexão se encontram alguns pressupostos fundamentais, como: (a) a de que há um conceito normativo de ciência; uma determinada categoria de saber, que se encontra à disposição de um sujeito cognoscente, cujos elementos constitutivos se afiguram como aprioristicamente dados; (b) o de que há um dado sujeito de conhecimento - cuja existência é dada pelo tempo presente; (c) o de que há igualmente um objeto de conhecimento que pode ser cognitivamente apreendido pelo sujeito cognoscente.

Para o combate de tal perspectiva cientificista, Habermas vai buscar subsídios, inicialmente e dentre outros, em Hegel, exatamente para testar a teoria do conhecimento clássica da Idade Moderna como mecanismo de apreensão de objetos de saber por sujeitos de saber, e o faz a partir de matrizes fenomenológicas, eis que: "A experiência fenomenológica se movimenta em uma dimensão onde as determinações transcendentais se autoconstituem. Nela não há um ponto de referência absolutamente seguro; tão somente a experiência da reflexão permite, enquanto tal, ser esclarecida sob a epígrafe do processo formativo". 5

Este processo formativo, por sua vez, está marcado por um universo de contingências e interesses que, a despeito de mutáveis, espelham o cenário societal a partir do qual se constituem e se transformam os atores sociais - que constituem e transformam aquele cenário. Assim, por óbvio que o conceito de interesse em Habermas não se apresenta como categoria com sentido universalmente dado ou enclausurado no tempo e espaço (a despeito que identificado no tempo e no espaço), mas vem forjado circunstancialmente pela historicidade que o envolve, ora sendo causa ora efeito das relações de força que marcam as relações intersubjetivas e materiais dos sujeitos sociais.

menti telematici, compito dello Stato è anche quello di diffondere le conoscenze per l'uso degli strumenti telematici quanto più ampiamente possibile; in caso contrario si rischia di costruire società di classi in cui il potere resterà confinato nelle mani di una élite di uomini tecnologici".

4. O que o autor denomina de Erkenntnisleitende Interessen. Habermas, Jürgen. Conhecimento e interesse. Rio de Janeiro: Civilização Brasileira, 1987. p. 27.

5. Habermas, Jürgen. Op. cit., p. 39. Ver também o texto de Deflem, Mathieu. Habermas, modernity and law. London: Sage Publication, 1996. p. 36. 
Por outro lado, naquelas ações humanas que visam não só atingir pragmaticamente um fim de caráter não necessariamente coletivo é possível perceber-se outro tipo de interesse, fundamentalmente comunicativo, que fomenta os homens a se relacionarem entre si por meio de normas linguisticamente articuladas/negociadas, e cujo objetivo é o entendimento mútuo, servindo a uma finalidade mais fundamental: o da emancipação da espécie. ${ }^{6}$

Aquela ideologia tecnocrática, a partir de definição de seu campo de prioridades e de ação - instrumental/estratégica para atingir fins previamente postos como prioritários universalmente -, afasta quaisquer outros problemas de caráter social, filosófico ou político do centro de atenção e de ação dos sujeitos sociais.

Já sobre as condições de validade ou competência do conhecimento a partir da perspectiva da comunicação não coatada pela ideologia tecnocrática, em cada situação de fala existem quatro "expectativas" a serem cumpridas (Geltungsansprüche): (a) a de que os conteúdos transmitidos são compreensíveis; (b) a de que os interlocutores são verazes; (c) a de que os conteúdos proposicionais são verdadeiros; e a (d) de que o locutor, ao praticar o ato linguístico em questão (afirmando, prometendo, ordenando), tinha razões válidas para fazê-lo, isto é, agia de acordo com normas que lhe pareciam justificadas. ${ }^{7}$

Ocorre que a ideologia tecnocrática impede a tematização discursiva do político, excluindo da comunicação pública certos temas e motivos inconvenientes para o sistema de poder, e que poderiam, precisamente, levar os indivíduos a promoverem a abertura de discursos problematizadores.

Para se chegar à comunicação não coatada, entende Habermas que todos os interessados precisam ter condições para participar do discurso, e que todos eles tenham oportunidades idênticas de argumentar, dentro dos sistemas conceituais existentes ou os transcendendo, e chances simétricas de fazer e refutar afirmações, interpretações e recomendações, supondo também que só são admitidos ao discurso aqueles participantes que, como atores, agiam de acordo com normas que lhes pareciam justificáveis e não movidos pela coação, e sa-

6. "O conhecimento instrumental permite ao homem satisfazer as suas necessidades ajudando-o a libertar-se da natureza exterior (por meio da produção); o conhecimento comunicativo o impele a se emancipar de todas as formas de repressão social (ou de seus representantes intrapsíquicos)." Habermas, Jürgen. Op. cit., p. 45. Ver também o texto de $\mathrm{Winch}_{\mathrm{IN}}$ Peter. Understanding a primitive society. New York: Humanities Press, 1978. p. 24.

7. Habermas, Jürgen. Op. cit., p. 19. 
tisfaziam o pressuposto da veracidade, não mentindo nem intencionalmente, nem inconscientemente (neurose ou falsa consciência). Essas duas condições configuram o modelo da ação comunicativa pura: uma forma de interação (e de organização social) caracterizada pela eliminação de todas as formas de coação externa e interna, o que se apresenta como de difícil concreção cotidiana, funcionando como tipo ideal/ideia regulativa do que deveria ser (e, portanto, deve ser constantemente buscado). ${ }^{8}$

Resta claro, assim, que, no âmbito do tema de fundo que proponho aqui analisar, impõe-se para o seu tratamento a adoção de compromissos e comportamentos pautados por uma ética da responsabilidade com o outro e com as gerações presentes e futuras, oportunizando interconexões entre esfera pública e privada, passando a interagir com os atos privados de pessoas que, ou foram atingidas, ou foram autoras de regimes de força autoritários (estou falando tanto dos agentes públicos como os indivíduos da resistência violenta que se criou em face de tais circunstâncias, e que perpetraram atos de sequestro, tortura, desaparecimento e morte de pessoas).

Os níveis de democracia da sociedade contemporânea dependem dos respectivos índices de conhecimento, participação social em esferas de debate e decisão política, bem como da difusão das informações em seu cotidiano, única maneira legítima de propiciar ao cidadão se constituir como ator decisivo no espaço público. ${ }^{9}$ Neste ponto, comparto com Chequer na assertiva de que:

8. "O modelo da ação comunicativa pura e a situação linguística ideal são duas pressuposições (Unterstellungen) mutuamente vinculadas. Ambas podem ser contrafatuais, e quase sempre o são: o modelo da comunicação pura constitui um telos (utópico) da comunicação normal, que remete a uma ordem social ainda inexistente; a situação linguística ideal constitui um telos (igualmente utópico) que, uma vez alcançado, tornaria possível o discurso perfeito em condições também inexistentes. Ao mesmo tempo, ambos têm que ser pressupostos como já reais: sem essa presunção, a interação e o discurso seriam impossíveis. Nesse sentido, a utopia da vida perfeita e a do conhecimento total têm que ser vistas como de certa forma já reais; ao mesmo tempo, proporcionam paradigmas críticos que permitem criticar formas existentes de interação e discurso. Em suma, os homens não podem nem interagir, nem se comunicar discursivamente senão na perspectiva de uma ordem social não repressiva (caracterizada pela comunicação e pela situação linguística ideal), a qual, precisamente, não existe, mas que tais antecipações nos autorizam a definir como possível". Habermas, Jürgen. Op. cit., p. 20.

9. Neste modelo de democracia do qual falo, o Estado não tem a função exclusiva de garantir a igualdade de oportunidades aos diferentes projetos de institucionalidade democrática, mas deve também garantir padrões mínimos de inclusão e informação, 
"(...) a liberdade de expressão em sentido estrito não se confunde com o direito fundamental à liberdade de informação (acolhendo-se aqui uma concepção dual ou diferenciadora). De acordo com essa corrente de pensamento, a exigência da prova da verdade ou a existência de um necessário trabalho preparatório da informação são elementos exclusivos da liberdade de informação, já que esta se refere a fatos. A liberdade de expressão em sentido estrito, por se referir a ideias, opiniões, pensamentos, não está condicionada à verdade.

A liberdade de informação exige uma divulgação verdadeira sobre fatos de relevância pública e, portanto, capaz de oferecer interesse para a reta conformação de uma opinião pública livre, requisito básico de toda a sociedade democrática." 10

Importa agora verificar como esta discussão se projeta ao nível normativo, constitucional e infraconstitucional, exatamente para identificar as possibilidades de ação no tocante à matéria.

\section{Marcos normativos do direito fundamental À INFORMAÇÃO}

Em termos de historicidade internacional, é importante ter presente que desde o século XX a mutação normativa - notadamente constitucional - no Ocidente se deu com foco no âmbito dos Direitos Fundamentais Individuais e Sociais. ${ }^{11}$

Na Declaração Universal dos Direitos Humanos, pode-se encontrar um dispositivo (art. 19) que trata do direito de acesso à informação, garantindo que "toda pessoa tem direito à liberdade de opinião e expressão; este direito inclui a liberdade de, sem interferência, ter opiniões e de procurar, receber e

que tornem possível à cidadania ativa criar, monitorar, acompanhar e avaliar o desempenho dos projetos de governo e proteção da comunidade, assim como os níveis de efetividade democrática de suas instituições. Ver o excelente texto de Avritzer, Leonardo. Teoria democrática, esfera pública e participação local. Revista Sociologias, n. 2, ano 1, p. 18-43.

10. Chequer, Cláudio. A liberdade de expressão como direito fundamental preferencial prima facie (análise crítica e proposta de revisão ao padrão jurisprudencial brasileiro). Rio de Janeiro: Lúmen Júris, 2011. p. 12. É interessante que, conforme a pesquisa do autor, os Tribunais Constitucionais da Espanha, Alemanha e dos EUA, convergem no sentido de diferenciar estes direitos fundamentais de modo semelhante.

11. Sem esquecer, é óbvio, que a Declaração de Direitos do Homem e do Cidadão, de 26.08.1789, já dizia, no seu art. 15, que "a sociedade tem o direito de pedir contas a todo agente público pela sua administração". 
transmitir informações e ideias por quaisquer meios e independentemente de fronteiras". ${ }^{12}$

Da mesma forma na Convenção Americana de Direitos Humanos, de 1969, ${ }^{13}$ pode-se encontrar previsão clara no sentido de que toda pessoa tem o direito à liberdade de pensamento e de expressão, e que tal direito inclui a liberdade de procurar, receber e difundir informações e ideias de qualquer natureza, sem considerações de fronteiras, verbalmente ou por escrito, ou em forma impressa ou artística, ou por qualquer meio de sua escolha (art. 13). Ademais, o exercício deste direito não pode estar sujeito à censura prévia, mas às responsabilidades ulteriores, que devem ser expressamente previstas em lei e que se façam necessárias para assegurar tão somente o respeito dos direitos e da reputação das demais pessoas, e a proteção da segurança nacional, da ordem pública, da saúde ou da moral públicas.

A Declaração Internacional de Chapultepec, ${ }^{14}$ firmada pelo presidente Fernando Henrique Cardoso, em 1996, em conjunto com vários presidentes latino-americanos, estabelece, em seus princípios que: "Não há pessoas nem sociedades livres sem liberdade de expressão e de imprensa. O exercício desta não é uma concessão das autoridades; é um direito inalienável do povo. Toda pessoa tem o direito de buscar e receber informação, expressar opiniões e divulgá-las livremente. Além disto, refere o documento que as autoridades devem estar legalmente obrigadas a pôr à disposição dos cidadãos, de forma oportuna e equitativa, a informação gerada pelo setor público".

Assim tem se comportado as Constituições de parte significativa dos países Ocidentais, eis que:

"The right of access to official information is now protected by the constitutions of some 60 countries. At least 46, and arguably 53 of these expressly guarantee

12. Adotada e proclamada pela Res. 217 A (III), da Assembleia Geral das Nações Unidas em 10.12.1948.

13. Adotada e aberta à assinatura na Conferência Especializada Interamericana sobre Direitos Humanos, em San José de Costa Rica, em 22.11.1969 - ratificada pelo Brasil em 25.09.1992, DOU 09.11.1992; p. 15562-15567.

14. O documento foi adotado pela Conferência Hemisférica sobre Liberdade de Expressão realizada em Chapultepec, na cidade do México, em 11.03.1994. Ela não é um documento de governo, como são os acordos internacionais. Trata-se de uma carta de princípios assinada por chefes de estado, juristas e entidades ou cidadãos comuns. O compromisso foi assumido pelo Brasil quando o ex-presidente Fernando Henrique Cardoso assinou a declaração em 09.08.1996, sendo que o presidente Luis Inácio Lula da Silva deu continuidade ao trabalho renovando o compromisso no dia 03.05.2006. 
a "right" to "information" or "documents," or else impose an obligation on the government to make information available to the public. The top courts of six of these countries (Argentina, Canada, France, India, Israel and South Korea) have interpreted the constitution to recognize the right implicitly." 15

Especificando mais este mapeamento da forma com que o Direito à Informação se encontra disposto na ordem constitucional contemporânea, o documento referido dá conta de que:

(a) Em 11 países da América há previsão constitucional sobre tal direito, a saber: Brasil, Chile, Colômbia, Costa Rica, Equador, México, Nicarágua, Panamá, Paraguai, Peru e Venezuela;

(b) Em outros 17 países há uma clara garantia constitucional deste direito: Albânia, Bulgária, República Checa, Estônia, Finlândia, Grécia, Hungria, Lituânia, Moldova, Noruega, Polônia, Portugal, Romênia, Servia, Slovakia, Slovênia, Suíça;

(c) Igualmente na Ásia e Pacífico pode-se contar com as seguintes constituições: Nepal, Nova Zelândia, Paquistão, Nova Guiné, Filipinas, Tailândia;

(d) Na África, têm-se os seguintes países compromissados normativamente com o Direito à Informação: Camarões, República do Congo, Gana, Kênia, Madagascar, Marrocos, Moçambique, Senegal, África do Sul, Tanzânia e Uganda. ${ }^{16}$

Em algumas constituições de países como Azerbaijão, Macedônia, Rússia e Ucrânia, há a explícita garantia do direito de receber informações, mas não especificamente em relação aos órgãos públicos como fornecedores destas, razão

15. Constitucional protections of the right of information. Disponível em: [http://right2info.org/constitutional-protections-of-the-right-to]. Acesso em: 12.09.2011. Adverte o documento, todavia, que: "Constitutions that guarantee less than general right to government-held information are not included in this count. For instance, we do not include constitutions that guarantee a right only to personal information, or to environmental information, or extend the right only to journalists. Nor do we include in this count constitutions that recognize a "right to freely seek and receive information," or variations of that phrasing, for instance as part of the right to freedom of expression, unless case-law, actual practice and/or assessments of in-country experts support the conclusion that the right includes a general right to information. We do, however, include in this count a right to government-held information that is limited to information of public interest" (p. 3).

16. Idem, p. 4. Alerta o documento ainda que: "Top courts of at least nine of these countries have ruled that the constitutional right is enforceable in court even without enactment of an implementing law, including Chile, Costa Rica, India, Paraguay, the Philippines, South Africa, South Korea, Uganda and Uruguay". 
pela qual os Tribunais destes países têm progressivamente determinado que tal direito da cidadania também está associado e relacionado aos poderes estatais, devendo estes providenciar as informações postuladas - guardadas as situações impossíveis normativamente de serem publicizadas, como aquelas que envolvem segurança nacional ou perigo de Estado (tema igualmente polêmico na discussão contemporânea da questão). ${ }^{17}$

As constituições do Kênia, Panamá, Polônia, Sérvia e África do Sul, expressamente estendem o Direito à Informação às empresas e ou entidades que exercem funções públicas bem como às autoridades públicas, garantido as constituições do Kênia e da África do Sul o acesso a qualquer informação que é produzida ou está na posse de outra pessoa e é necessária/requerida para o exercício ou proteção de qualquer direito ou liberdade.

De outro lado, desde o caso Claude Reyes e outros contra o Governo Chileno, julgado em 19.09.2006, pela Corte Interamericana de Direitos Humanos, ${ }^{18}$ tem-se uma posição clara no âmbito latino-americano da jurisprudência internacional envolvendo esta matéria, reconhecendo o direito à informação como fundamental, em especial diante do Estado.

Tais posturas vêm alterando a própria compreensão da função institucional e social dos fundos e arquivos públicos, como bem adverte o Prof. Dr. Jaime Antunes:

"Com o advento das modernas tecnologias de controle e recuperação da informação, a visão de arquivo como instituição de guarda de documentos foi substituída por aquela que o situa enquanto gestor de um sistema de informação, integrado a outros sistemas, com o objetivo maior de garantir o acesso do usuário às informações demandadas. Ou seja, o eixo foi deslocado da questão da guarda para a do acesso." 19

Nesta linha de raciocínio, resta claro que os documentos e arquivos envolvendo temas de natureza pública - em especial os que dizem com aprendizagens democráticas necessárias - precisam ser manejados para além da conservação meramente histórica, impondo compreensão enquanto fontes de

17. PASk, Arthur. National order. Disponível em: [www.ccourt.go.kr/home/english/index. jsp]. Acesso em: 12.09.2011.

18. Disponível em: [www.soros.org/initiatives/justice/litigation/chile/d_decision-en_ 20060919.pdf]. Acesso em: 12.09.2011. Em especial ver também a Open Society Justice Initiative's Amicus Brief. Disponível em: [www.soros.org/initiatives/justice/litigation/chile/court-amicus-brief-3282006.pdf]. Acesso em: 19.09.2011.

19. Silva, Jaime Antunes. O centro de referência das lutas políticas no Brasil (1964-1985). Revista Acervo, vol. 21, n. 2, p. 14. 
informações que reclamam domínio e debate público emergente, até em face da dicção constitucional do art. 216, § 2. ${ }^{\circ}$, da CF/1988, ao disciplinar que cabe à Administração Pública a gestão da documentação governamental e as providências para franquear sua consulta a quantos dela necessitem.

Veja-se que a Corte Constitucional Italiana tratou bem de tema correlato a este (o do segredo de Estado), na linha do que tenho sustentado até aqui, ao dizer que:

"Il principio di segretezza esiste e resiste, rispetto ad altri valori costituzionali alla cui tutela è preposto l'ordinamento giurisdizionale, solo se trova fondamento in altre esigenze anch'esse costituzionali ma di rango superiore. La sua ragion d'essere è dunque nella finalizzazione al supremo interesse della sicurezza dello Stato nella sua personalità Internazionale, nella sua preordinazione alla tutela dell'interesse dello Stato-comunità alla propria integrità territoriale, alla propria indipendenza e, al limite, alla propria sopravvivenza." ${ }^{20}$

É importante ter claro que o sistema normativo italiano e sua jurisprudência hegemônica reconhece a natureza amplamente discricionária da avaliação categorizante do Segredo de Estado (alla salus rei publicae), sendo a autoridade pública responsável por tal mister o Presidente do Conselho de Ministros, enquanto órgão no vértice da organização governamental deste país, o que vem regulado pelos termos do art. 95, da sua Constituição.

No julgamento referido, a Corte Constitucional deixa claro que o segredo é somente legítimo quando se apresenta como necessário à tutela efetiva e demonstrada dos interesses nacionais referentes ao Estado, o que se distingue de forma absoluta dos interesses conjunturais de qualquer um dos Poderes de Estado instituídos (Legislativo, Executivo e Judiciário), ou mesmo de partidos políticos, interesses corporativos ou individuais, destacando che mai il segreto potrebbe essere allegato per impedire l'accertamento di fatti lesivi dell'ordine costituzionale. ${ }^{21}$

20. Corte Costituzionale. Sentença n. 19/28, junho de 2002, n. 295. Gazzetta Ufficiale, Parte I, 1. ${ }^{a}$ Serie Speciale, n. 26 del 03.07.2002, p. 28. Francesco Manganaro lembra que: "La 'costituzionalizzazione' di tale interesse viene quindi individuato dalla Consulta negli artt. 52 e 126 della Carta costituzionale, ove si fa riferimento al concetto di 'sicurezza nazionale'. Il concetto di 'difesa' trova, invece, specificazione nell'art. 87 (Consiglio Supremo di Difesa) che, posto in connessione con gli artt. 5 e 1 ('che riassume i caratteri essenziali dello Stato stesso nella formula di 'repubblica democratica"'), rende possibile attribuire contenuto concreto alla nozione di segreto. MANGAnaro, Francesco; Romano Tassone, Antonio (a cura di). I nuovi diritti di cittadinanza. Torino: Giappichelli, 2005, p. 119.

21. Idem. 
E no Brasil em especial, como está a configuração normativa constitucional e infraconstitucional da matéria sob comento?

A Constituição de 1988, em seu art. 5. ${ }^{\circ}$, IV, IX e XIV, dentre outros, dispôs que: (a) é livre a manifestação do pensamento, sendo vedado o anonimato (IV); (b) é livre a expressão da atividade intelectual, artística, científica e de comunicação, independentemente de censura ou licença (IX); (c) é assegurado a todos o acesso à informação e resguardado o sigilo da fonte, quando necessário ao exercício profissional (XIV).

Já no que tange à Administração Pública, o art. 37, caput, e o art. 93, IX e $\mathrm{X}$, ambos da Carta Política, dispuseram que são públicos os atos e negócios da Administração Pública no país, observadas as situações que envolvem segurança nacional ou congênere.

Com maior grau de especificidade, pelos termos da Lei federal 9.784/1999, que regula os procedimentos administrativos, de igual sorte restaram consolidados direitos e garantias da cidadania - e da Administração - no atendimento de demandas, inclusive de informação, que se apresentam a esta.

Por tais razões se pode dizer com Sandulli que é regra constitucional do agir administrativo a sua transparência, eis que: "costituisce un'esigenza assolutamente fondamentale degli ordinamenti democratici, ponendosi come strumento indispensabile a realizzare un effettivo e diretto rapporto tra governanti e governati, per il fatto di consentire a questi ultimi una più consapevole partecipazione all'operato dei pubblici poteri e un più pieno controllo della relativa rispondenza agli interessi sociali e ai precetti legislativi e costituzionali" ${ }^{22}$

Mas em termos operacionais, o que significa esta transparência administrativa? Junto com a participação nos procedimentos administrativos, à motivação e publicidade dos atos administrativos, dar a conhecer os documentos públicos.

Agora, em um ordenamento jurídico como o brasileiro, em que vige a exigência da documentação administrativa - decorrente dos princípios informativos do art. 37, caput, da CF/1988 -, o direito de acesso constitui, se não o principal, certamente um dos parâmetros fundamentais para colocar à prova a maturidade do sistema como um todo e verificar a possibilidade de afirmar e concretizar esta centralidade que o cidadão possui no âmbito da gestão do in-

22. Romano, Santi. Principii di diritto amministrativo. Milano: Giuffrè, 1906. p. 22. Ainda refere o autor que: "il diritto di accesso, ponendosi come momento di attuazione del principio di partecipazione e quale strumento di controllo dei cittadini sull'imparzialità della pubblica amministrazione, deve diventare come regola, generale ed immanente, dell'ordinamento giuridico italiano". 
teresse público. Assim, "per definizione, accesso si contrappone a segretezza. Il binomio implica un rapporto inversamente proporzionale tra i termini: minore è il grado di segretazione, maggiore è la possibilità di accedere ai documenti" ${ }^{23}$

Como já disse, a informação e o acesso a ela hoje se afiguram como condição de possibilidade da própria Democracia, da Igualdade e Liberdade, assim como da dignidade da pessoa humana. Na perspectiva habermasiana isto significa que a democracia contemporânea deve estar baseada em um modelo teórico e pragmático dual, relacionado não apenas com a formação da vontade, institucionalizada no complexo parlamentar, mas também com uma noção de esfera pública que é reenviada a um conjunto espontaneamente gerado de arenas políticas informais, dialogicamente discursivas, e ao próprio contexto cultural respectivo, afigurando-se como uma oposição binária entre o plano formal e institucionalizado da democracia e os domínios informais e anárquicos de formação da opinião. ${ }^{24}$

Vai na mesma direção Ana Graf:

"O direito às informações de que o Estado dispõe se fundamenta no princípio da publicidade dos atos administrativos e na eliminação dos segredos públicos. Neste sentido, o direito à informação constitui um indicador significativo dos avanços em direção a uma democracia participativa: oponível ao Estado, comprova a adoção do princípio da publicidade dos atos administrativos; sob o ponto de vista do cidadão, é instrumento de controle social do poder e pressuposto da participação popular, na medida em que o habilita para interferir efetivamente nas decisões governamentais e, se analisado em conjunto com a liberdade de imprensa e banimento da censura, também funciona como instrumento de controle social do poder." 25

23. Arena, Gregório. Il segreto amministrativo. Padova: Cedam, 2004, p. 34. Refere ainda o autor que: "l'accesso ai documenti amministrativi, attese le sue rilevanti finalità di pubblico interesse, costituisce principio generale dell'attività amministrativa al fine di favorire la partecipazione e di assicurarne l'imparzialità e la trasparenza".

24. O conceito de esfera pública aqui tem natureza política e constitucional, eis que pretende destacar a importância do sentimento de pertencimento do cidadão à sua realidade espacial e temporal, no sentido de corresponsável pela constituição do espaço público em que vive, a partir de pautas normativas que ele ajudou a demarcar, com objetivos, finalidades e valores a serem perseguidos. Ver neste sentido o texto de VIROLI, Maurizio. For love of country. an essay on patriotism and nationalism. Oxford: Clarendon Press, 1995, assim como o texto de Bunchaft, Maria Eugenia. Patriotismo constitucional na perspectiva de Jürgen Habermas. Rio de Janeiro: Lumen Juris, 2010.

25. Graf, Ana Cláudia Bento. O direito à informação ambiental, direito ambiental em evolução apud GuERRA, Sidney. O direito à informação como ferramenta de proteção ao meio ambiente no Mercosul. Revista Ibero-Americana de Direito Público, vol. 05, p. 205. 
Neste modelo de democracia do qual falo, o Estado não tem a função exclusiva de garantir a igualdade de oportunidades aos diferentes projetos de institucionalidade democrática, mas deve também garantir padrões mínimos de inclusão e informação, que tornem possível à cidadania ativa criar, monitorar, acompanhar e avaliar o desempenho dos projetos de governo e proteção da comunidade. Esses padrões mínimos são indispensáveis para transformar a instabilidade institucional em campo de deliberação democrática. ${ }^{26}$

No âmbito do texto constitucional brasileiro vigente se pode destacar algumas previsões normativas muito claras nesta direção, dentre as quais, no plano formal, tratando de requisitos instrumentais da participação e do controle social da administração pública:

(a) a exigência de publicidade dos atos da Administração, para os fins de garantir um grau de visibilidade do poder político e social, dela não podendo constar nomes, símbolos ou imagens que caracterizem promoção pessoal de autoridades ou servidores públicos, ${ }^{27}$ ao mesmo tempo em que se impõe como requisito de vigência da norma legal; ${ }^{28}$

(b) o direito do cidadão em obter certidões do Poder Público, visando trazer informações oficiais sobre interesses pessoais e determinados, consoante disposição constitucional inscrita no art. $5^{\circ}, \mathrm{XXXIV}$, da CF/1988;

(c) o direito de petição, garantido a qualquer pessoa, independentemente de ser ou não cidadão, alcançando aos três poderes do Estado, para os fins de defesa de direitos ou contra ilegalidade ou abuso de poder, nos termos do art. 5. ${ }^{\circ}, \mathrm{XXXIV}, a$, da CF/1988.

Por tais argumentos é que o Segredo Administrativo de Estado não tem vez nos regimes democráticos contemporâneos, sendo até possível, em raríssimas e muito bem justificadas situações, aceitar-se a existência da informação e do

26. Vai neste sentido decisão da Corte Alemã ao dizer que: "A liberdade de informação é, precisamente, o direito a se informar. Por outra parte, este direito de liberdade é o pressuposto da formação da opinião que precede a expressão desta. Pois só a informação completa possibilita uma livre formação e expressão da opinião tanto para o indivíduo como para a sociedade". Chequer, Cláudio. Op. cit., p. 14.

27. Nos termos do art. 37, caput e $\S 1 .^{\circ}$, da CF/1988, destacando-se esta publicidade como princípio informativo da própria Administração Pública.

28. Cumpre destacar que a publicidade, neste particular, não é elemento formativo do ato, necessário a existência válida deste ato, salvo quando a lei o dispuser, mas será sempre requisito de sua eficácia, exequibilidade e moralidade. Neste sentido, ver o texto de Moreira Neto, Diogo de Figueiredo. Direito de participação política. Rio de Janeiro: Renovar, 1993. p. 107 e ss. 
documento secreto não mais reportado à posição do seu detentor ou produtor, mas à qualidade da informação/documento envolvido e o que protege, superando-se, desta maneira, o fundamento meramente subjetivo e pessoal do segredo administrativo - um documento é segredo porque pertence à Administração Pública, ou porque o Administrador o produziu ou assim o entende -; mas pelo fato de representar uma concessão objetiva e real (tal documento/informação é segredo em face da qualidade da informação que contém, justificado normativa e racionalmente).

Em face disto, evidencia-se como demasiadamente contraditório o fato de que o Brasil tenha, por iniciativa governamental, pela via do Dec. 5.584/2005, determinado o envio de fundos documentais atinentes ao regime militar ao Arquivo Nacional, até então sob a guarda da Agência Brasileira de Inteligência - Abin, dos extintos Serviço Nacional de Informações - SNI (1964-1990), da Comissão Geral de Investigações - CGI (1964-1979), e do Conselho de Segurança Nacional - CSN (1964-1980), Divisão de Segurança e Informações do Ministério da Justiça - DSI/MJ (1946-1986), Divisão de Inteligência da Polícia Federal (1960-1990) e, ao mesmo tempo, não tenha gerado políticas públicas de acesso integral a este universo de informações acumuladas, mas, pelo contrário, vem criando obstáculos para tal ocorrer. ${ }^{29}$

Por outro lado, não se pode esquecer que o art. 5. ${ }^{\circ}$, XXXIII, da CF/1988, ao disciplinar que todos têm direito a receber dos órgãos públicos informações de seu interesse particular, ou de interesse coletivo ou geral, que serão prestadas no prazo da lei, sob pena de responsabilidade, ressalvou aquelas cujo sigilo seja imprescindivel à segurança da sociedade e do Estado.

Mas, afinal, quais são as informações cujo sigilo seja imprescindível à segurança da sociedade e do Estado? Quem define, e como o faz, os critérios de eleição desta imprescindibilidade? De que tipo de segurança se está falando aqui em face da sociedade e do Estado? Estas questões demandam reflexão e respostas preliminares, as quais devem tomar como referência obrigatória,

29. Conforme o excelente trabalho de Jaime Antunes citado constam de tais acervos várias espécies de documentos, desde impressos, processos, microfilmes, microfichas, fotografias, mapas, plantas e desenhos correspondentes, com aproximadamente 9.926.000 páginas de textos. Até 2009, o Arquivo Nacional já contava com 11.468.676 de páginas de texto em termos de documentos atinentes a este período de exceção, sendo que a Coordenação Regional do Arquivo Nacional no Distrito Federal vem recebendo outros fundos documentais similares, recolhidos, até 2009, 39 acervos, com 1.291.775 metros lineares, 220.000 microfichas e 84 rolos de microfilmes (ou 16.258.676 de folhas de documentos), abrangendo o período de 1934/2009. Op. cit., p. 17-18. 
dentre outros, os marcos normativos constitucionais e infraconstitucionais aplicados no caso.

Não estou sustentando aqui que o Direito à Informação seja absolutamente autônomo em face dos demais direitos albergados pelo ordenamento jurídico brasileiro, mas há que se tencionar ao menos os argumentos de fundamentação e justificação da suas restrições - este também um Direito Fundamental. ${ }^{30}$

Como quer Crisafulli, há pelos menos duas formas de se compreender o Direito à Informação hodiernamente, uma em sentido lato e outra em sentido estrito: "la prima attiene a quel duplice ordine di situazioni soggettive consistenti nella libertà di informare e nella libertà di informarsi; la seconda, invece, è un'espressione che può essere usata per indicare in maniera più specifica quella situazione soggettiva derivante dal diritto all'informazione come libertà di informarsi (ossia di ricevere e ricercare informazioni)", e é desta segunda que estou tratando aqui. ${ }^{31}$

O evolver legislativo desta matéria no plano da infraconstitucionalidade no Brasil, todavia, é truncado no particular, bastar ver, de forma exemplificativa, a sucessão de regulamentações que se teve à espécie.

Um dos principais documentos normativos infraconstitucionais que o país teve sobre a matéria foi o Dec. 79.099/1977 (revogado), editado em pleno regime militar, pelo então Presidente, General Ernesto Geisel, e que lançou os marcos conceituais preliminares sobre a matéria que os demais institutos jurídicos basicamente repetiram, chegando as minúcias de definir categorias próprias de blindagem e segredo documental, a saber, a título exemplificativo:

"Art. 2. ${ }^{\circ}$ Para os fins deste Regulamento serão consideradas as seguintes conceituações:

Acesso - Possibilidade e ou oportunidade de obter conhecimento de assunto sigiloso.

Área sigilosa - Área em que se situam instalações, edificações ou imóveis de qualquer tipo, ou somente parte deles, que requeira a adoção de medidas espe-

30. Digo isto porque tenho presente a existência de posições doutrinárias e jurisprudenciais - inclusive internacionais - que sustentam a autonomia deste direito, ex vi: "Un secondo e più illuminato orientamento, invece, ha successivamente sostenuto e dimostrato, con estrema convinzione, l'idea di un diritto all'informazione come diritto del tutto autonomo e unitario sotto il profilo della sua configurazione fattuale". Loiodice, Carlo. Contributo allo studio sulla libertà d'informazione. Napoli: Giuffrè, 2002. p. 39.

31. Crisafulli, Vezio. Problematica della libertà d'informazione. Rivista Il Político 8/65. 
ciais em proveito da segurança de assuntos sigilosos que nela sejam tratados, manuseados ou guardados.

Assunto sigiloso - É aquele que, por sua natureza, deva ser do conhecimento restrito e, portanto, requeira medidas especiais para sua segurança.

Classificar - Atribuir um grau de sigiloso a um material, documento ou área que contenha ou utilize assunto sigiloso.

Comprometimento - Perda de segurança resultante de obtenção, por pessoa não autorizada, do conhecimento de assunto sigiloso.

Credencial de segurança - Certificado, concedido por autoridade competente, que habilita uma pessoa a ter acesso a assunto sigiloso.

Custódia - Responsabilidade pela segurança de assunto sigiloso, decorrente da posse de material ou documento sigiloso.

Documento sigiloso - Documento impresso, datilografado, gravado, desenhado, manuscrito, fotografado ou reproduzido que contenha assunto sigiloso.

Grau de sigilo - Gradação atribuída a um assunto sigiloso, de acordo com a natureza de seu conteúdo e tendo em vista a conveniência de limitar sua divulgação às pessoas que tenham necessidade de conhecê-lo.

Investigação para credenciamento - Investigação feita com o propósito de verificar se determinada pessoa possui os requisitos indispensáveis para receber Credencial de Segurança.

Material sigiloso - Toda matéria, substância ou artefato que, por sua natureza, deva ser do conhecimento restrito, por conter e ou utilizar assunto sigiloso.

Necessidade de conhecer - É a condição, inerente ao efetivo exercício de cargo, função ou atividade, indispensável para que uma pessoa, possuidora da Credencial de Segurança adequada, tenha acesso a assunto sigiloso.

Visita - Pessoa cuja entrada foi admitida, em caráter excepcional, em área sigilosa de organização privada ou do Governo."

Com base em tais elementos, o governo militar efetivamente autorizou a gestão confidencial de documentos que, a seu juízo, poderiam expor as forças armadas e suas ações de ordem e segurança públicas.

Isto restou tão evidente que, nos termos do art. $3 .^{\circ}$ caput e parágrafo único do Dec. 79.099/1977, ficou assentado que: "Os assuntos sigilosos serão classificados, de acordo com a sua natureza ou finalidade e em função da sua necessidade de segurança, em um dos seguintes graus de sigilo: ultra-secreto, secreto, confidencial e reservado. Parágrafo único. A necessidade de segurança será avaliada mediante estimativa dos prejuízos que a divulgação não autoriza- 
da do assunto sigiloso poderia causar aos interesses nacionais, a entidades ou indivíduos". ${ }^{32}$

Por outro lado, ciosa de sua hegemonia institucional e de força, as forças armadas sequer se preocuparam em disfarçar que, ao fim e ao cabo, os assuntos sigilosos veiculados por quaisquer documentos assim enquadrados seriam classificados de acordo com o seu conteúdo e não, necessariamente, em razão de suas relações com outro assunto (art. 5. ${ }^{\circ}$ do Dec. 79.099/1977), ou seja, permitindo juízos discricionários a respeito do tema. ${ }^{33}$

32. Veja-se que, pelos termos do art. $68, \S 1 .^{\circ}$, "Para a guarda de documentos ultra-secretos é obrigatório o uso de cofre com segredo de, no mínimo, três combinações ou material que ofereça segurança equivalente. Na falta destes, os documentos ultra-secretos deverão ser mantidos sob guarda armada" - o mesmo valento para os documentos secretos.

33. A despeito de estabelecer o mesmo diploma legal, em seu art. $5 .^{\circ}$, e parágrafos, as situações fáticas de enquadramento das modalidades de sigilo enunciadas pela norma: "§ 1. ${ }^{\circ}$ São assuntos normalmente classificados como ultra-secreto aqueles da política governamental de alto nível e segredos de Estado, tais como: - negociações para alianças políticas e militares; - hipóteses e planos de guerra; - descobertas e experiências científicas de valor excepcional; - Informações sobre política estrangeira de alto nível; $\S 2 .^{\circ}$ São assuntos normalmente classificados como secreto os referentes a planos, programas e medidas governamentais, os extraídos de assunto ultra-secreto que, sem comprometer o excepcional grau de sigilo do original, necessitem de maior difusão, bem como as ordens de execução, cujo conhecimento prévio, não autorizado, possa comprometer suas finalidades. Poderão ser secretos, entre outros, os seguintes assuntos: - planos ou detalhes de operações militares; - planos ou detalhes de operações econômicas ou financeiras; - aperfeiçoamento em técnicas ou materiais já existentes; - Informes ou Informações sobre dados de elevado interesse relativos a aspectos físicos, políticos, econômicos, psicossociais e militares nacionais ou de países estrangeiros; - materiais de importância nos setores de criptografia, comunicações e processamento de informações;

$\S 3$. $^{\circ}$ São assuntos normalmente classificados como confidencial os referentes a pessoal, material, finanças etc., cujo sigilo deva ser mantido por interesse do Governo e das partes, tais como: - Informes e Informações sobre atividades de pessoas e entidades; - ordens de execução cuja difusão prévia não seja recomendada; - radiofrequências de importância especial ou aquelas que devam ser frequentemente trocados; - indicativos de chamada de especial importância que devam ser frequentemente distribuídos; - cartas, fotografias aéreas e negativos, nacionais e estrangeiros, que indiquem instalações consideradas importantes para a Segurança Nacional. § 4. ${ }^{\circ}$ São assuntos normalmente classificados como reservado os que não devam ser do conhecimento do público em geral, tais como: - outros Informes e Informações; - assuntos técnicos; - partes de planos, programas e projetos e suas respectivas ordens de execução; - cartas, fotografias aéreas e negativos, nacionais e estrangeiros, que indiquem instalações importantes". 
O curioso é que o Decreto ainda tratava de estratégias para que a confidencialidade não descambasse para o excesso, não porque isto poderia violar Direito Fundamental, mas pelo fato de que: "A classificação exagerada retarda, desnecessariamente, o trato de assuntos e deprecia a importância do grau de sigilo. Deste modo, o critério para a classificação deve ser o menos restritivo possível" (art. 9. ${ }^{\circ}$ do Dec. 79.099/1977). Mas o menos restritivo possível para quem? Por certo que para o regime de exceção.

E agora o mais impressionante: Qual o critério para que se possa conseguir uma Credencial de Segurança a fim de permitir o acesso a documentos ditos sigilosos? "Para a concessão de Credencial de Segurança os seguintes requisitos pessoais, entre outros, deverão ser avaliados através de investigação para credenciamento: - lealdade e confiança; - caráter e integridade moral; - hábitos e atitudes no trato com assunto sigiloso; - ligações e amizades". ${ }^{34}$

No início da década de 1990 já se alinhavam as normativas sobre o tema em conformação à Constituição de 1988, como bem mostra a Lei federal 8.159/1991, ao assegurar que: (a) "Todos têm direito a receber dos órgãos públicos informações de seu interesse particular ou de interesse coletivo ou geral, contidas em documentos de arquivos, que serão prestadas no prazo da lei, sob pena de responsabilidade, ressalvadas aquelas cujo sigilo seja imprescindível à segurança da sociedade e do Estado, bem como à inviolabilidade da intimidade, da vida privada, da honra e da imagem das pessoas" (art. 4. ${ }^{\circ}$ ); (b) "A Administração Pública franqueará a consulta aos documentos públicos na forma desta lei" (art. 5. ${ }^{\circ}$ ); (c) Mesmo para os casos de que tal publicização destes documentos venham a gerar algum tipo de violação de direito a pessoas físicas ou jurídicas, estabelecia que restaria "resguardado o direito de indenização pelo dano material ou moral decorrente da violação do sigilo, sem prejuízo das ações penal, civil e administrativa" (art. 6. ${ }^{\circ}$ ).

O problema é o que vem disposto no capítulo $\mathrm{V}$, desta norma, em especial em seu art. 22, que de um lado garante ser assegurado o acesso pleno de documentos, mas, em seu art. 23, coloca restrições e limitadores para tanto, ao prever que: "§ $1 .{ }^{\circ}$ Os documentos cuja divulgação ponha em risco a segurança da sociedade e do Estado, bem como aqueles necessários ao resguardo da inviolabilidade da intimidade, da vida privada, da honra e da imagem das pessoas são originariamente sigilosos"; "§ 2. ${ }^{\circ} \mathrm{O}$ acesso aos documentos sigilosos referentes à segurança da sociedade e do Estado será restrito por um prazo máximo de 30 (trinta) anos, a contar da data de sua produção, podendo esse prazo ser pror-

34. Art. 22 do do Dec. 79.099/1977. 
rogado, por uma única vez, por igual período"; "§ 3. $\mathrm{O}$ acesso aos documentos sigilosos referente à honra e à imagem das pessoas será restrito por um prazo máximo de 100 (cem) anos, a contar da sua data de produção". 35

Como se abrindo uma brecha na blindagem da informação destes documentos, prevê o art. 24 da Lei 8.159/1991 que "Poderá o Poder Judiciário, em qualquer instância, determinar a exibição reservada de qualquer documento sigiloso, sempre que indispensável à defesa de direito próprio ou esclarecimento de situação pessoal da parte".

Pergunta-se: com esta dicção legal somente Direitos Individuais serão passíveis de autorizar intervenção judicial para garantia de acesso e conhecimento, eis que Direitos Sociais Difusos à Informação - como os que se quer alcançar com a Comissão da Verdade - estarão inacessíveis pelo prazo da lei? Ou se pode pensar num certo direito subjetivo público indisponível - envolvendo amplo conceito de Direito Fundamental Civil ${ }^{36}$ - que se cria com a busca da Verdade e Memória daqueles períodos de exceção no país?

E mais, que tipologia de informações devem ter os documentos para serem considerados necessários ao resguardo da inviolabilidade da intimidade, da vida privada, da honra e da imagem das pessoas ? Como e quem vai aferir isto, e com base em que critérios e juízos de valor? Há elementos objetivos para estas demarcações conceituais? Quem os definiu e com base em que procedimentos? Poderia imperar aqui a proteção a posteriori - com o dano consumado?

Poder-se-ia inclusive perquirir se os anteriores documentos sigilosos referente à honra e à imagem das pessoas restritos por um prazo máximo de 100 anos, a contar da sua data de produção, não seriam os mesmos dos referidos no art. 23, \& 2. ${ }^{\circ}$, da Lei 8.159/1991, criando zona de incerteza a favor da discricionariedade do agente público que os catalogar, o que torna mais difícil o controle social, político e mesmo jurisdicional da matéria.

É interessante notar que em 24.02.1997, o Presidente Fernando Henrique Cardoso faz publicar o Dec. 2.134/1997 (posteriormente revogado pelo Dec.

35. Art. 23, $\S \S 1 .^{\circ}, 2 .^{\circ}$ e $3 .^{\circ}$, da Lei federal 8.159/1991.

36. Aliás, "Civil rights are the protections and privileges of personal liberty given to all citizens by law. Examples of civil rights and liberties include the right to get redress if injured by another, the right to privacy, the right of peaceful protest, the right to a fair investigation and trial if suspected of a crime, and more generally-based constitutional rights such as the right to vote, the right to personal liberty, the right to life, the right to freedom of movement, the right to business and profession, the right to freedom of speech and expression". Inter-American Court of Human Rights. Claude Reyes et al vs. Chile... cit. 
4.553/2002), regulamentando a Lei 8.159/1991, e ampliando de certa forma o acesso à informação de determinados documentos tidos como sigilosos ao estabelecer regras de catalogação e desclassificação destes, e com isto tornando-os mais ostensivos à Sociedade Civil, isto porque:

(a) determinava, o art. $4{ }^{\circ}$ do Dec. 2.134/1997, que qualquer documento classificado como sigiloso, recolhido a instituição arquivística pública, que em algum momento tenha sido objeto de consulta pública, não poderia sofrer restrição de acesso;

(b) fora determinada a criação, pelos órgãos públicos e as instituições de caráter público, custodiadores de documentos sigilosos, de Comissões Permanentes de Acesso, para o cumprimento deste Decreto, podendo ser criadas subcomissões (art. 5. ${ }^{\circ}$ do Dec. 2.134/1997);

(c) estabeleceu que as Comissões Permanentes de Acesso deveriam analisar, periodicamente, os documentos sigilosos sob custódia, submetendo-os à autoridade responsável pela classificação, a qual, no prazo regulamentar, efetuaria, se fosse o caso, sua desclassificação (art. 6. ${ }^{\circ}$ do Dec. 2.134/1997); ${ }^{37}$

(d) no que tange aos documentos que continham informações pessoais, eles seriam liberados à consulta pública desde que previamente autorizada pelo titular ou por seus herdeiros (art. (. $^{\circ}$ ), sendo que as Comissões Permanentes de Acesso poderiam autorizar o acesso a documentos públicos de natureza sigilosa a pessoas devidamente credenciadas, mediante apresentação, por escrito, dos objetivos da pesquisa (art. 9. ${ }^{\circ}$ do Dec. 2.134/1997);

(e) restou disposto de forma clara neste Decreto que a eventual negativa de autorização de acesso deveria ser justificada por escrito (art. 12 do Dec. 2.134/1997), o que facilitaria o controle da legalidade e legitimidade dos comportamentos arquivísticos.

O pesquisador Carlos Fico, em artigo publicado na Revista Acervo, do Arquivo Nacional, ${ }^{38}$ refere que em outubro de 2001 (portanto, quatro anos de-

37. Imagina-se que estas Comissões Permanentes de Acesso observassem procedimentos administrativos de discussão e deliberação sobre matéria tão importante, assim como fundamentasse e justificasse todas elas, com registros formais próprios, até porque a relação dos documentos desclassificados, contendo nome e sigla do órgão ou da instituição, tipo, número e data do documento, grau de sigilo original, destinatário e assunto, deveria ser encaminhada, semestralmente, por estas Comissões, para publicação no Diário Oficial da União, do Distrito Federal, dos Estados ou dos Municípios, conforme o caso - Art. 6. ${ }^{\circ}$, parágrafo único, do Dec. 2.134/1997.

38. Fico, Carlos. A ditadura documentada: acervos desclassificados do regime militar brasileiro. Revista Acervo, vol. 21, n. 2, p. 67 e ss. 
pois da normativa ter sido criada) recebeu a notícia do Gabinete de Segurança Institucional da Presidência da República, de que a Agência Brasileira de Inteligência (Abin) havia nomeado Comissão Permanente de Acesso para avaliar os documentos pertencentes ao extinto Conselho de Segurança Nacional, mas que, em face da quantidade e diversidade de documentação relacionadas, o trabalho ainda não havia sido concluído, razão pela qual não poderiam disponibilizar os referidos documentos.

A par destes avanços na regulamentação da matéria, o Decreto foi tímido na questão da conceituação restritiva de arquivos e documentos, classificando-os em: (a) ultra-secretos: os que requeiram excepcionais medidas de segurança e cujo teor só deva ser do conhecimento de agentes públicos ligados ao seu estudo e manuseio; (b) secretos: os que requeiram rigorosas medidas de segurança e cujo teor ou característica possam ser do conhecimento de agentes públicos que, embora sem ligação íntima com seu estudo ou manuseio, sejam autorizados a deles tomarem conhecimento em razão de sua responsabilidade funcional; (c) confidenciais: aqueles cujo conhecimento e divulgação possam ser prejudiciais ao interesse do país; (d) reservados: aqueles que não devam, imediatamente, ser do conhecimento do público em geral (art. 15 do Dec. 2.134/1997).

Eis os níveis de extrema abertura dos conceitos construídos pelo Decreto presidencial!

Ou seja, além da via eleita para tais demarcações categoriais de alta significação política e jurídica - porque restringem o acesso à informação da sociedade civil sobre temas de interesse público evidente -, ser esvaziadora do debate público democrático (sequer contou com a discussão pontual e específica do Parlamento enquanto representante popular), os próprios termos indicados à catalogação dos documentos se prestam a múltiplas manipulações hermenêuticas redutoras de possibilidades sócio-eficaciais atinentes à informação e conhecimento das questões que veiculam.

Afinal, quem vai definir, e como vai definir o que são as excepcionais medidas de segurança de cujo teor só deva ser do conhecimento de agentes públicos ligados ao seu estudo e manuseio atinentes aos documentos ultra-secretos? Quais são as rigorosas medidas de segurança passíveis de bloquearem o acesso aos documentos ditos secretos? Quem os define e como os define? Que conteúdos de documentos ou fonte produtora podem ser classificados como prejudiciais ao interesse do país para os fins de classificação documental confidencial? Quem os define e como os define? E quanto aos chamados documentos reservados, quais os critérios de delimitação daquilo que não deve ser de imediato conhecimento público? Qual a dimensão temporal da expressão imediato? Quem define isto e como define? 
O Decreto tentou espancar estes interrogantes com algumas disposições tais quais as do art. 16, afirmando que "são documentos passíveis de classificação como ultra-secretos aqueles referentes à soberania e integridade territorial nacionais, planos de guerra e relações internacionais do País, cuja divulgação ponha em risco a segurança da sociedade e do Estado". E andou bem neste sentido, porque ao menos densificou materialmente os casos mais objetivos de enquadramento da categoria tratada, todavia, de forma monocrática (Decreto Presidencial) e não coletiva (por que não o Congresso Nacional?).

Não bastasse isto, os legitimados à decisão de quando se encontram presentes aquelas situações de classificação documental são ainda mais reduzidos, a saber: "A classificação de documento na categoria ultra-secreta somente poderá ser feita pelos chefes dos Poderes Executivo, Legislativo e Judiciário federais" (art. 16, parágrafo único, do Dec. 2.134/1997).

O fez também no âmbito dos documentos secretos, aduzindo que se referem "a planos ou detalhes de operações militares, a informações que indiquem instalações estratégicas e aos assuntos diplomáticos que requeiram rigorosas medidas de segurança, cuja divulgação ponha em risco a segurança da sociedade e do Estado" (art. 17 do Dec. 2.134/1997), outorgando competência à classificação documental na categoria somente às "autoridades indicadas no parágrafo único do art. 16 deste Decreto, por governadores e ministros de Estado, ou, ainda, por quem haja recebido delegação" (art. 17, parágrafo único, do Dec. 2.134/1997). O problema é que o $§ 2 .^{\circ}$, do mesmo artigo, radicalizou a subjetividade desta decisão, ao dizer que: "A competência prevista no $\S 1$. deste artigo poderá ser subdelegada” (Incluído pelo Dec. 4.497/2002).

Nos chamados documentos confidenciais não foi diferente, uma vez que o art. 18, do mesmo estatuto, definiu que estes se caracterizam quando "o sigilo deva ser mantido por interesse do governo e das partes, e cuja divulgação prévia possa vir a frustrar seus objetivos ou ponha em risco a segurança da sociedade e do Estado", sendo que tal classificação somente poderá ser feita por: (a) pelos chefes dos Poderes Executivo, Legislativo e Judiciário federais; (b) por governadores e ministros de Estado; (c) pelos titulares dos órgãos da Administração Pública Federal, do Distrito Federal, dos Estados e dos Municípios; (d) por quem haja recebido delegação.

Surge de forma direta aqui a questão de quando se apresentam as condições nas quais devam os documentos ser mantidos em sigilo em face de interesse governamental ou de partes? Quem as define e como se dá isto? Ademais, que interesses governamentais ou pessoais podem inviabilizar o conhecimento público uma vez que versam sobre matérias de natureza pública inconteste? 
Por sua vez, os documentos tidos como reservados, entendidos pelo art. 19 do Dec. 2.134/1997, desta normativa, como "aqueles cuja divulgação, quando ainda em trâmite, comprometa as operações ou objetivos neles previstos", tiveram sua classificação outorgada aos seguintes agentes públicos: (a) aos chefes dos Poderes Executivo, Legislativo e Judiciário federais; (b) aos governadores e ministros de Estado; (c) aos titulares dos órgãos da Administração Pública Federal, do Distrito Federal, dos Estados e dos Municípios; (d) a quem haja recebido delegação; (e) aos agentes públicos formalmente encarregados da execução de projetos, planos e programas.

Veja-se que, em termos de prazos de classificação, o Decreto, em seu art. 20 do Dec. 2.134/1997, determinava que seriam os seguintes: (I) ultra-secretos, máximo de 30 anos; (II) secretos, máximo de vinte anos; (III) confidenciais, máximo de 10 anos; (IV) reservados, máximo de 5 anos.

É interessante que, nos termos das dicções dos art. 22 e 23, "a autoridade responsável pela classificação dos documentos, ou a autoridade mais elevada, findo o motivo de sua classificação ou alteração de sua natureza, e considerando o interesse para a pesquisa e para a administração", poderia alterar ou mesmo cancelar a classificação, "tornando-os ostensivos". Ao mesmo tempo, considerando o interesse da segurança da sociedade e do Estado, poderia renovar a classificação por uma única vez, por igual período; e mais, poderia a autoridade superior à que classificou o documento alterar o grau de sigilo dos documentos em trâmite, o que mostra o resquício autoritário.

Havia ainda outra engenhosa ferramenta de manejo/manipulação desta documentação no âmbito do Decreto sob comento que diz com a chamada credencial de segurança documental, ou seja, o selo identificatório da classificação do documento, eis que o seu art. 25 do Dec. 2.134/1997, dispôs que os procedimentos específicos à espécie seriam objeto de disposições internas de cada órgão ou instituição de caráter público, os quais levariam em conta as diretrizes e conceitos abertos acima enfocados, portanto, com excessivo juízo de discricionariedade inclusive axiológica.

Por fim, o Decreto, em seus art. 28 e 29, ainda excetuou do acesso público irrestrito "os documentos cuja divulgação comprometa a intimidade, a vida privada, a honra e a imagem das pessoas, e aqueles integrantes de processos judiciais que tenham tramitado em segredo de justiça", tornando-os "restritos pelo prazo de cem anos, a partir da data de sua produção", criando uma excepcionalidade misteriosa para que se permitisse o acesso (art. 29, parágrafo único, do Dec. 2.134/1997), desde que autorizado pelas Comissões Permanentes de Acesso, mas somente a pessoas devidamente credenciadas, mediante apresentação, por escrito, dos objetivos da pesquisa (art. 9. ${ }^{\circ}$ ). 
Então veja-se a incongruência da regulação: (a) é vedado o acesso a documentos cuja divulgação comprometa a intimidade, a vida privada, a honra e a imagem das pessoas, mas ao mesmo tempo não se esclarece de que pessoas se fala: se as que produziram os documentos ou as que foram alvo das informações veiculadas pelos documentos (algozes ou vítimas); tampouco são indicados os critérios que serão utilizados pelas Comissões Permanentes de Acesso - se é que são elas que irão exercer os juízos de valor necessários aqui e, a partir disto, deliberar o quê e quando se caracteriza comprometimento dos interesses envolvidos - para tais tomadas de decisões (sequer há procedimentos públicos previstos no particular).

Não bastasse isto, no final do segundo governo do Presidente Fernando Henrique Cardoso, fora editado o Dec. 4.553/2002, retrocedendo o tratamento destas questões, na medida em que ampliou significativamente os prazos à classificação dos documentos (ou seja, o tempo em que ficariam indisponíveis ao acesso público), a saber: (a) os documentos reservados que tinham prazo de classificação de 5 anos passaram para 10 anos; (b) os documentos confidenciais que tinham prazo de classificação de 10 anos passaram para 20 anos; (c) os documentos secretos que tinham prazo de classificação de 20 anos passaram para 30 anos; (d) os documentos ultra-secretos, com prazo de classificação inicial estabelecidos em 50 anos, poderiam ser sigilosos eternamente. ${ }^{39}$ Como diz Fico: "Além disso, as regras para a desclassificação tornaram-se confusas. As comissões de acesso foram eliminadas, o Executivo passou a ser o único poder competente para a atribuição de sigilo e o número de autoridades com tal poder aumentou". ${ }^{40}$

Somente em 09.12.2004, através do Dec. 5.301/2004, o governo federal regulamentou a MedProv 228/2004, determinando a "criação, no âmbito da Casa Civil da Presidência da República, da Comissão de Averiguação e Análise de Informações Sigilosas, com a finalidade de decidir pela aplicação da ressalva prevista na parte final do inc. XXXIII do art. 5. ${ }^{\circ}$ da CF/1988", restaurando um pouco os prejuízos opostos ao acesso público das informações e acervos sob comento.

39. O retrocesso foi tanto que este novo diploma legal chegou a estabelecer a possibilidade de classificar partes de um mesmo documento (art. 13 do Dec. 4.553/2002): "As páginas, os parágrafos, as seções, as partes componentes ou os anexos de um documento sigiloso podem merecer diferentes classificações, mas ao documento, no seu todo, será atribuído o grau de sigilo mais elevado, conferido a quaisquer de suas partes".

40. Fico, Carlos. Op. cit, p. 74. 
O referido decreto determinou que a composição da Comissão de Averiguação e Análise de Informações Sigilosas contasse com os seguintes membros: Ministro de Estado Chefe da Casa Civil da Presidência da República (coordenador), Ministro de Estado Chefe do Gabinete de Segurança Institucional da Presidência da República, Ministro de Estado da Justiça, Ministro de Estado da Defesa, Ministro de Estado das Relações Exteriores, Advogado-Geral da União, e Secretário Especial dos Direitos Humanos da Presidência da República.

Nos termos do § 2..$^{\circ}$ do art. $4 .^{\circ}$ do Dec. 5.301/2004, facultou-se à Comissão, para o exercício de suas atribuições, a convocação de "técnicos e especialistas de áreas relacionadas com a informação contida em documento público classificado no mais alto grau de sigilo, para sobre ele prestarem esclarecimentos, desde que assinem termo de manutenção de sigilo", cabendo a Casa Civil da Presidência da República expedir normas complementares necessárias ao funcionamento da Comissão, assegurando o apoio técnico e administrativo indispensável ao seu funcionamento $\left(\S 4 .^{\circ}\right)$.

O problema é que este diploma legal autorizou que "a autoridade competente para classificar o documento público no mais alto grau de sigilo", por juízo de discricionariedade absolutamente subjetivo, possa, "após vencido o prazo ou sua prorrogação, previstos no $\S 2 .^{\circ}$ do art. 23 da Lei 8.159/991, provocar, de modo justificado, a manifestação da Comissão de Averiguação e Análise de Informações Sigilosas para que avalie, previamente a qualquer divulgação, se o acesso ao documento acarretará dano à segurança da sociedade e do Estado" (art. 5. ${ }^{\circ}$ do Dec. 5.301/2004).

Ou seja, o primeiro juízo de valoração sobre a matéria é monocrático da autoridade estatal, podendo ou não levar esta questão de alta relevância política e social ao órgão colegiado e mais democrático que é a Comissão sob comento.

No $\S 1 .^{\circ}$ do art. $5 .^{\circ}$ do Dec. 5.301/2004, até de forma paradoxal, retira-se o poder absoluto daquela autoridade competente nas situações em que pessoas que demonstrem possuir efetivo interesse no acesso à determinada informação, venham a provocar diretamente a Comissão para os fins de revisão da classificação de documento público no mais alto grau de sigilo, podendo, aqui, a Comissão fazê-lo. Para tanto, o interessado deverá especificar, de modo claro e objetivo, que informação pretende conhecer e qual forma de acesso requer, dentre as seguintes: vista de documentos, reprodução de documentos por qualquer meio para tanto adequado, ou pedido de certidão, a ser expedida pelo órgão consultado (art. 5. ${ }^{\circ}, \S 2 .^{\circ}$, do Dec. 5.301/2004), não estando obrigado, todavia, a "aduzir razões no requerimento de informações, salvo a comprovação de seu efetivo interesse na obtenção da informação" (art. 5. ${ }^{\circ}, \S$ 3. ${ }^{\circ}$, do Dec. 5.301/2004). 
Por outro lado, dando sequência ao tratamento que os anteriores dispositivos imprimiram à matéria, a MedProv 228/2004 fez registrar que, em face do disposto no art. $5 .^{\circ}, \mathrm{X}$, da CF/1988, os documentos públicos que deixassem de ser classificados no mais alto grau de sigilo, mas que contivessem informações relacionadas à intimidade, vida privada, honra e imagem de pessoas, teriam suas informações disponíveis ao acesso da pessoa diretamente interessada ou, em se tratando de morto ou ausente, do seu cônjuge, ascendentes ou descendentes no prazo de que trata o art. 23, § 3. ${ }^{\circ}$, da Lei 8.159/1991..$^{41}$

Até poder-se-ia questionar se esta previsão da Medida Provisória indicada teria sua validade garantida em face de não ter sido alcançada pelos termos da regulamentação do Dec. 5.301/2004. Ocorre que a regulamentação citada não tem o condão de exaurir os termos da Medida Provisória, mas apenas estabelecer procedimentos de execução material e formal da matéria. Ademais, em 05.05.2005, a referida Medida Provisória foi transformada em Lei federal 11.111/2005, estabilizando, assim, a regulação do tema, inclusive abrandando de certa forma os documentos envolvendo o disposto no art. 5. ${ }^{\circ}, \mathrm{X}$, da CF/1988, ao dizer que:

"Art. 7. ${ }^{\circ}$ Os documentos públicos que contenham informações relacionadas à intimidade, vida privada, honra e imagem de pessoas, e que sejam ou venham a ser de livre acesso poderão ser franqueados por meio de certidão ou cópia do documento, que expurgue ou oculte a parte sobre a qual recai o disposto no inciso $X$ do caput do art. 5. ${ }^{\circ}$ da Constituição Federal.

Parágrafo único. As informações sobre as quais recai o disposto no inciso $\mathrm{X}$ do caput do art. $5 .^{\circ}$ da Constituição Federal terão o seu acesso restrito à pessoa diretamente interessada ou, em se tratando de morto ou ausente, ao seu cônjuge, ascendentes ou descendentes, no prazo de que trata o \& 3. ${ }^{\circ}$ do art. 23 da Lei 8.159, de 8 de janeiro de 1991."

Deste emaranhado de normas jurídicas, ao fim e ao cabo, restou formalmente patenteado no país a possibilidade de consulta a documentos com altíssimos níveis de classificação inibitória ao acesso às informações que veiculam, entretanto, com índices de imprecisão e aberturas semânticas impressionantes no que tange às suas classificações, e ainda, para ultimar, delegando a competência liberatória para órgão que, ao que parece, até agora não mostrou a que veio - sequer se veio, a saber, as referidas Comissões de Averiguação e Análise de Informações Sigilosas, conforme matéria jornalística que reproduzo:

41. Diz a norma que "o acesso aos documentos sigilosos referentes à honra e à imagem das pessoas será restrito por um prazo máximo de 100 (cem) anos, a contar da sua data de produção". 
"Governo não organiza os dados sigilosos. Casa Civil deveria criar a Comissão de Averiguação e Análise de Informações Sigilosas

À exceção do MRE, a organização dos documentos sigilosos de 9 entre os 10 mais estratégicos órgãos do governo ainda engatinha. Nem o Gabinete de Segurança Institucional da Presidência (GSI) e os ministérios da Defesa e da Justiça sabem quantos arquivos classificados estão sob sua tutela. Na última semana, a discussão sobre o sigilo de documentos ultrassecretos causou polêmica no país. E a sinalização da presidente Dilma Rousseff (PT) em favor do segredo constrangeu a Câmara, que aprovou projeto no sentido oposto. A reportagem consultou 10 ministérios com potencial para guardar informações sigilosas. Desde a Controladoria Geral da União (CGU) ao Ministério de Desenvolvimento, Indústria e Comércio Exterior (MDInd), passando por Banco Central, Fazenda e Secretaria de Assuntos Estratégicos (SAE). Em todos, as informações nunca foram sistematizadas. De acordo com a Lei 11.111/2005, a Casa Civil da Presidência deveria criar a Comissão de Averiguação e Análise de Informações Sigilosas para 'decidir sobre a aplicação da ressalva ao acesso de documentos' no Poder Executivo. Mas, na prática, cada órgão segue seu próprio ritmo e tem suas próprias diretrizes de classificação, que não ficam claras para a sociedade. A comissão existe, mas sequer determinou aos ministérios que sistematizassem o fluxo de informações classificadas. Ao GSI, órgão que desde 1999 gerencia informações da vida palaciana - como a rotina dos presidentes da República - a reportagem perguntou sobre o número de arquivos sigilosos, sua classificação e quais argumentos são utilizados para o enquadramento em cada caso. A resposta veio em breve comunicado. "Em resposta às suas indagações, informamos que o Gabinete de Segurança Institucional, a exemplo dos demais órgãos da Administração Pública Federal, cumpre o prescrito no Dec. $4.553 / 2002$, que regula a salvaguarda de dados, informações, documentos e materiais sigilosos de interesse da segurança da sociedade e do Estado e elabora, no momento, uma síntese do acervo existente", informou." ${ }^{42}$

O jornal Folha de São Paulo, em sua edição de 23.09.2011, página A9, com matéria intitulada Arquivo sigiloso de órgão de segurança tem 70 mil papéis, dá conta de que o Gabinete de Segurança Institucional da Presidência da República - GSI (o mesmo referido na matéria acima citada), informou ao Senado Federal que guarda mais de 69.000 documentos sigilosos, incluindo os produ-

42. Disponível em: [http://gazetaonline.globo.com/_conteudo/2011/06/noticias/a_gazeta/politica/883018-governo-nao-organiza-os-dados-sigilosos.html], publicado no sítio do Jornal Gazeta Online. Acesso em: 27.09.2011. 
zidos pela Agência Brasileira de Informação - ABIn, dividindo-se em quatro tipos de arquivos: dois ultra-secretos, 4.116 secretos, 56.644 confidenciais e 8.344 reservados.

Diz ainda a matéria que o Senador relator do projeto de lei que altera a classificação e os prazos de armazenamento de documentos oficiais, restou indignado em face das informações deficitárias enviadas pelo GSI, sugerindo até apresentar pedido de esclarecimentos ao setor responsável.

Ou seja, para além das questões de ordem jurídica - que são sérias -, há problemas de gestão e (des)organização institucional para com estes acervos públicos, o que reclama medidas enérgicas do governo sob pena de se inviabilizar os trabalhos da própria Comissão da Verdade que acaba de ser aprovada pela Câmara dos Deputados do Brasil.

Aliás, esta foi a conclusão da Comissão Interamericana de Direitos Humanos de São José da Costa Rica, no caso Gomes Lund e Outros ("Guerrilha do Araguaia") vs. Brasil, ${ }^{43}$ ao dizer que:

"Adicionalmente, as diversas leis e decretos que tem regido o direito de acesso à informação no Brasil não cumprem com os parâmetros estabelecidos pelo Sistema Interamericano, dado que o alcance e o conteúdo do direito de acesso à informação está regulamentado por disposições de caráter administrativo e nenhuma das normas de regulamentação desse direito define nem delimita as causas de restrição. Ademais, essas disposições: a) não incluem procedimentos administrativos que assegurem a correta tramitação e resolução de solicitações de informação, os prazos para contestar, nem a possibilidade de impugnar a negativa de facilitar a informação através de um recurso rápido e efetivo; b) não contemplam a obrigação de fundamentar adequadamente as negativas à solicitação de informação, e c) contemplam períodos de restrição ilegítimos."

Por tais razões, entendeu a Comissão que os Estados têm a obrigação positiva de produzir e conservar informação, o que os obriga a buscá-la e implementar medidas que permitam a custódia, o manejo e o acesso aos arquivos.

A jurisprudência brasileira não tem tido muitas oportunidades para tratar deste assunto no particular, a despeito de reconhecer que a Lei Fundamental garante o direito à "obtenção de certidões em repartições públicas, para a defesa de direitos e esclarecimentos de situações de interesse pessoal" (art. 5. ', XXXIV, $b$, da CF/1988), e o "direito a receber dos órgãos públicos informações de seu interesse particular, ou de interesse coletivo ou geral, que serão prestadas no prazo da lei, sob pena de responsabilidade, ressalvadas aquelas cujo sigilo seja

43. Sentença de 24.11.2010, item n.184, f. 
imprescindível à segurança da sociedade e do Estado" (art. 5. ${ }^{\circ}$, XXXIII, da CF/1988), lembrando inclusive que a Lei 9.051/1995, regulamentou o direito a certidões, prevendo que o interessado, na petição, faça constar a finalidade da certidão e as razões do pedido. Por tais razões, se afiguraria inexistente direito líquido e certo à obtenção de informações quando formulado à Administração Pública pedido genérico e imotivado. ${ }^{44}$

O STJ teve oportunidade também de se referir ao Direito à Informação como Direito Social, que:

"Constitucional e administrativo. Recurso ordinário. Mandado de segurança coletivo. Partido dos trabalhadores e parlamentares estaduais. Governo do Paraná. Protocolo de intenções celebrado com Renaut do Brasil Automóveis S/A. Instalação de montadora de veículos no Estado. Exibição de documentos do interesse da coletividade. Art. 5. ${ }^{\circ}$, XXXIII, da CF.

1. Dentre os direitos e garantias fundamentais capitulados no art. 5. ${ }^{\circ} \mathrm{da} \mathrm{CF} / 1988$ está inserido o de que "todos têm direito de receber dos órgãos públicos informações de seu interesse particular, ou de interesse coletivo em geral, que serão prestadas no prazo de lei, sob pena de responsabilidade, ressalvadas aquelas cujo sigilo seja imprescindível à segurança da sociedade e do Estado" (inciso XXXIII).

2. Inequívoco que os documentos cuja exibição foi requerida pelos impetrantes não estão protegidos pelo sigilo prescrito no art. 38 da Lei estadual 1.595/1964, sendo sua publicidade indispensável à demonstração da transparência dos negócios realizados pela Administração Pública envolvendo interesses patrimoniais e sociais da coletividade como um todo.

3. Recurso ordinário conhecido e provido para, reformando o acórdão impugnado, conceder a segurança nos termos do pedido formulado pelos recorrentes." 45

Nesta lógica de raciocínio, tem-se que, mesmo superados todos estes entraves normativos, ainda assim ter-se-ia o problema de delimitar melhor os procedimentos, critérios e formas de deliberação das chamadas Comissões de Averiguação e Análise de Informações Sigilosas, não se podendo aceitar que tamanha responsabilidade para os fins de classificar ou desclassificar documentos (que significa torná-los públicos ou não) que dizem com a Verdade e Memória deste

44. Neste sentido as decisões do STJ: RO em MS 32.740/RJ, 1. ${ }^{a}$ T., j. 01.03.2011, rel. Min. Arnaldo Esteves Lima, DJe 17.03.2011; RO em MS 32.748/RJ (2010/0147887-2), 2. ${ }^{a}$ T., j. 14.06.2011, rel. Min. Herman Benjamin, DJe 31.08.2011; RO em MS 20.412/PR, 2. ${ }^{a}$ T., j. 06.03.2008, rel. Min. Eliana Calmon, DJe 25.03.2008; RO em MS 18.564/RJ, 1. ${ }^{\mathrm{a}}$ T, j. 09.11.2004, rel. Min. Francisco Falcão, DJ 13.12.2004.

45. RO em MS 10.131/PR, 2. ${ }^{a}$ T., j. 07.11.2000, rel. Min. Peçanha Martins, DJ 18.02.2002. 
país, reste cingida à boa vontade e exercício subjetivo dos seus membros, que inclusive, ao que tudo indica, poderão ter formatos, operacionalizações, comportamentos e resultados de acordo com cada órgão detentor destes acervos o que implica absoluta falta de controle social e político sobre o que vão fazer.

Daí a importância de se pensar em instituir também procedimentos públicos de atuação, controle e resultados àquelas Comissões, permitindo com isto maior participação social e mesmo institucional dos Poderes do Estado.

\section{Bibliografia}

Arena, Gregório. Il segreto amministrativo. Padova: Cedam, 2004.

Avritzer, Leonardo. Teoria democrática, esfera pública e participação local. Revista Sociologias. n. 2. ano 1. p. 18. Porto Alegre: UFRGS, jul.-dez. 1999.

Brugaletta, Francesco. Poteri pubblici e dovere di disseminazione: l'altra faccia del diritto all'informazione. Rivista Diritto $\&$ Diritti. Disponível em: [www. diritto.it/articoli/informatica/relazionedue.html]. Acesso em: 21.10.2011.

Bunchaft, Maria Eugenia. Patriotismo constitucional na perspectiva de Jürgen $\mathrm{Ha}$ bermas. Rio de Janeiro: Lumen Juris, 2010.

CHequer, Cláudio. A liberdade de expressão como direito fundamental preferencial prima facie (análise crítica e proposta de revisão ao padrão jurisprudencial brasileiro). Rio de Janeiro: Lumen Juris, 2011.

Constitucional protections of the right to information. Disponível em: [http:// right2info.org/constitutional-protections-of-the-right-to]. Right 2 info. Law $\&$ practice. Acesso em: 12.09.2011.

Corte Costituzionale. Sentença n. 19/28, junho de 2002, n. 295. Gazzetta Ufficiale, Parte I, 1. ${ }^{a}$ Serie Speciale, n. 26 del 03.07.2002.

Crisafulli, Vezio. Problematica della libertà d'informazione. Rivista Il Político. n. 8. p. 65. Milano: Daltrice, 1962.

Deflem, Mathieu. Habermas, modernity and law. London: Sage Publication, 1996.

Della Torre, Zucchetti. Privacy e accesso ai documenti amministrativi. Roma: Giuffrè, 2009.

Fico, Carlos. A ditadura documentada: acervos desclassificados do regime militar brasileiro. Revista Acervo. vol. 21. n. 2. p. 67. Rio de Janeiro: Arquivo Nacional, jul.-dez. 2008.

Governo não organiza dados sigilosos. Disponível em: [http://gazetaonline. globo.com/_conteudo/2011/06/noticias/a_gazeta/politica/883018-governo-nao-organiza-os-dados-sigilosos.html]. Jornal Gazeta Online, em 18.06.2011. Acesso em 27.09.2011.

GUERRA, Sidney. O direito à informação como ferramenta de proteção ao meio ambiente no Mercosul. Revista Ibero-Americana de Direito Público. vol. 5. p. 205. Rio de Janeiro: América Jurídica, 2001. 
Habermas, Jürgen. Conhecimento e interesse. Rio de Janeiro: Civilização Brasileira, 1987.

Inter-American Court of Human Rights. Case n. 12.108. Marcel Claude Reyes and Others vs. Chile. Written comments of: Open Society Justice Initiative. Article 19, Global campaign for free expression libertad de información Mexico Instituto Prensa y Sociedad Access info Europe, March 2006. Disponível em: [www.soros.org/initiatives/justice/litigation/chile/court-amicus-brief-3282006.pdf]. Acesso em: 18.09.2011.

Inter-American Court of Human Rights. Appendix. Claude Reyes et al. vs. Chile. Judgment of September 19, 2006. Disponível em: [www.soros.org/ initiatives/justice/litigation/chile/d_decision-en_20060919.pdf]. Acesso em: 12.09.2011.

Loiodice, Carlo. Contributo allo studio sulla libertà d'informazione. Napoli: Giuffrè, 2002.

Manganaro, Francesco; Romano Tassone, Antonio (a cura di). I nuovi diritti di cittadinanza. Torino: Giappichelli, 2005.

Moreira Neto, Diogo de Figueiredo. Direito de participação política. Rio de Janeiro: Renovar, 1993.

Orestano, Ricardo. Sulla problemática del segreto. Roma: Mulino, 2009.

PAsk, Arthur. National order. Disponível em: [www.ccourt.go.kr/home/english/ index.jsp]. Acesso em: 12.09.2011.

Romano, Santi. Principii di diritto amministrativo. Milano: Giuffrè, 1906.

Silva, Jaime Antunes. O centro de referência das lutas políticas no Brasil (19641985). Revista Acervo. vol. 21. n. 2. p. 14. Rio de Janeiro: Arquivo Nacional, jul.-dez. 2008.

Viroli, Maurizio. For love of country. An essay on patriotism and nationalism. Oxford: Clarendon Press, 1995.

Winch, Peter. Understanding a primitive society. New York: Humanities Press, 1978.

\section{Pesouisas do Editorial}

\section{Veja também Doutrina}

- Direito à memória e reparação: da inclusão jurídica das pessoas perseguidas e torturadas na ditadura militar brasileira, de Irene Patrícia Nohara - RDCl 67/125; e

- 0 Estado-membro e a política nacional de arquivos públicos e privados, de José Edgard Penna Amorim Pereira - RDCl 24/149. 